1998

\title{
The Role of State Government in Nuclear Power Regulation: Jurisdictional Conflicts in the US
}

Donald N. Zillman

University of Maine School of Law, donald.zillman@maine.edu

Follow this and additional works at: http://digitalcommons.mainelaw.maine.edu/facultypublications

Part of the Energy and Utilities Law Commons

\section{Suggested Bluebook Citation}

Donald N. Zillman, The Role of State Government in Nuclear Power Regulation: Jurisdictional Conflicts in the US, 16 J. Energy \& Nat. Resources L. 16 (1998).

Available at: http://digitalcommons.mainelaw.maine.edu/faculty-publications/25 


\section{The Role of State Government in Nuclear Power Regulation: Jurisdictional Conflicts in the US}

\section{By Donald N Zillman*}

\footnotetext{
* The Author is Dean and Edward Godfrey Professor at the University of Maine School of Law. In January 1996 he was appointed by Governor Angus King to serve as a reviewer of the allegations of criminal wrongdoing in connection with the 1989 Licence Change at Maine Yankee. In June 1996 he was appointed by the Governor as one of five members of the Citizen's Review Team of the Independent Safety Assessment of Maine Yankee. University of Maine School of Law, Portland, Maine, USA. Tel: 1-207-780-4344. Fax: 1-207-780-4239. E-mail: DON@payson.usm.main.edu Or zillman@usm.maine.edu
}

The regulation of nuclear power in the United States provides ample opportunity for conflicts over jurisdiction. The Maine Yankee case demonstrates the complications that arise as a result. The article concludes, however, that state involvement in the federal process can be both useful and collaborative.

\section{Introduction}

The United States deserves much of the credit or blame for the creation of nuclear power. The atomic bomb projects of the $1940 \mathrm{~s}$ and the nuclear navy of the 1950 s gave rise to peaceful nuclear projects in the forms of massive electric generating facilities in the 1960s. A nuclear future seemed likely.

Then a combination of circumstances stopped the nuclear electric programme. Cost-overruns, safety fears, unexpected downturns in the costs of competing fuels, rational and irrational popular opposition, the Three Mile Island and Chernobyl incidents all helped damage American nuclear development. By the late 1970s new orders for nuclear plants had stopped. By the mid-1990s the earliest of the existing plants were nearing the end of their licensed and physical lives. Newer plants were struggling with high costs. All operating plants were facing a new deregulated world of electric power sales in which companies could no longer rely on government-mandated paybacks of the cost of plant construction and operation. Nuclear 
power shows ample signs of being a 'one generation and out' technology in the United States.

Yet, a decade in energy policy can be an eternity. If we believe past predictions, we will soon have OPEC ruling the world, coal too dirty to burn, petroleum at over $\$ 100$ per barrel, and solar energy beginning to dominate parts of the world's energy picture. A combination of factors could restore nuclear power to being the fuel of the future.

For now, regulatory issues loom large in deciding the future of American nuclear power. Regulatory and promotional decisions by the United States government have kept nuclear power either cost advantageous or cost competitive with other energy sources. Regulation has demanded safety, but has it been enough? No other energy source has a 'worst case accident' potential similar to nuclear power.

1996 provided a troubling 12 months for American nuclear power. Several plants faced serious challenges to their continued existence. The Nuclear Regulatory Commission, the federal government's watchdog on nuclear safety, was criticised on its competence and integrity as a new Chairman, Shirley Jackson, tried to assert her authority. Corporate owners struggled over whether to continue to sink dollars into nuclear technology.

Many of these issues came into focus in the State of Maine, where the state's single nuclear plant, Maine Yankee, suffered through what could charitably be called a bad year. Its bad year troubled investors, management, nuclear supporters and opponents, and parts of state government, most notably Maine's Governor. This is the story of that year and following months. Our particular focus is on the position of the State of Maine in nuclear regulation, a job typically the province of the private owners of the nuclear plant and the officials of the United States Nuclear Regulatory Commission.

\section{Maine Yankee}

The Maine Yankee nuclear power plant can be viewed as a product of American nuclear energy's golden age. It was planned in the 1960s when opposition to peaceful nuclear uses was sporadic. Licensing procedures were routine bureaucratic exercises.

The plant was a single unit pressurised water reactor. It is located on an inlet of the Maine coast near Wiscasset, the self-proclaimed 'prettiest village in Maine'. It is about 40 miles from Maine's largest city, Portland, which in turn, is about 100 miles from the Boston metropolitan area. Maine Yankee is owned by a consortium of New England electric companies. The largest owner is Central Maine Power Company, Maine's largest electric utility. Half of Maine Yankee is owned by Maine utilities; the other half by out-of-state companies. Similarly, about half of Maine Yankee power stays in Maine where it supplies between 20-25 per cent of the state's electricity. The remaining power is shipped out of Maine, primarily to supply New England markets. The major owners make up most of the Board 
of Directors of Maine Yankee and appoint its Chief Executive Officer.

Maine Yankee has characterised its first 22 years as highly successful. The claim has merit. The plant was built on time and on budget. It earned a reputation with the Nuclear Regulatory Commission, that matched its name - frugal, a bit aloof, but competent. It also built a reputation for carrying out one of nuclear energy's great promises - generating large amounts of cheap energy.

The major threat to Maine Yankee in these years was not financial or legal. It was political. Following the 1979 accident at Three Mile Island, two statewide referenda tried to close the plant by vote of the citizens of Maine. A third referenda was attempted in 1987 after the Chernobyl accident in the Ukraine. Each vote failed. While the issues differed and the Maine Yankee supporters substantially outspent their opponents, it seemed fair to conclude that a solid majority of Maine citizens backed a plant that appeared to offer inexpensive power under reasonably safe operating conditions.

One of Maine Yankee's major involvements with federal regulation and regulators was to ask for and get power increases allowing it to generate more total power at ever-cheaper unit costs. The NRC approved an increase to $2630 \mathrm{Mw}_{\text {th }}$ in 1978 and a further increase to $2700 \mathrm{Mw}_{\text {th }}$ in 1989. Maine Yankee was generating the lowest cost power of any large generator in Maine. It had also positioned itself as the single New England nuclear plant whose costs allowed it to remain competitive if open competition came to the previously closed markets for electric power. But good news was about to become rare for Maine Yankee.

\section{Regulation of nuclear energy in the United States}

The law of United States nuclear electric generation can be summed up in a few paragraphs. These legal realities structured the relationship among Maine Yankee, the United States, and the State of Maine during the 'time of troubles' in 1995-97.

After the success of the atomic bomb project and the end of World War II in 1945, the United States Congress faced several crucial decisions about nuclear energy. In retrospect, Congress may have erred, but it was decisive. First, Congress put control of the nuclear process in civilian, not military, hands. Second, in matters of nuclear security and safety the federal government displaced the traditional role of the States as guardians of citizen's health and safety. Third, in 1954 Congress authorised private industry to play the lead role in the development of peaceful uses of the atom. Congress, through federal agencies, would closely monitor security and radiation safety. But, private investors would build the nuclear plants and run them. Fourth, Congress took an unapologetic pro-nuclear stance. Government did not merely allow nuclear technology. It encouraged it with large taxpayer subsidies to research and development and a pronuclear regulatory posture. 
These steps had built the world's largest nuclear industrial community by 1978 when Maine Yankee received its power upgrade to $2630 \mathrm{Mw}_{\mathrm{th}}$ By that time, nuclear opponents were organising and turning any nuclear plant licensing into administrative law warfare with advocates on both sides finding little room for compromise. Nuclear opponents also began to raise 'state and local' issues. Why should the plant's neighbours take the risk of accidents?

Federal law sided with the nuclear power industry. The Atomic Energy Act spoke of the goal of encouraging 'widespread participation in the development and utilisation of atomic energy for peaceful purposes to the maximum extent consistent with the common defence and security and with the health and safety of the public ...' The section of the Act addressing federal cooperation with the States recognised 'the need . . . for cooperation between the States and the Commission with respect to control of radiation hazards associated with the use of [nuclear material],' and authorised Commission transfer of jurisdiction to the States. ${ }^{2}$ However, the statute forbade the Commission from surrendering jurisdiction over 'the construction and operation of any production or utilisation facility', to wit, a nuclear electric plant. ${ }^{3}$ The States could, however, collaborate with a willing Commission in licensing and regulatory work.

The major area for State autonomy (matters not needing a Commission consent) was addressed in section 2021(k): 'Nothing in this section shall be construed to affect the authority of any State or local agency to regulate activities for purposes other than protection against radiation hazards.' 4

The United States Supreme Court addressed sec 2021(k)'s allocation of jurisdiction in 1983 in Pacific Gas and Electric $v$ Energy Resources Conservation and Development Commission. ${ }^{5}$ The State of California enacted a statute in response to concem over the failure to find a long-term solution to the disposition of highly radioactive spent nuclear fuel. The statute imposed a moratorium on the certification of new nuclear plants until the California Energy Commission certified that the United States had approved 'a demonstrated technology or means for the disposal of high-level nuclear waste'. The Energy Commission's finding was subject to disapproval by the California Legislature.

California defended the statute against charges that it intruded on federal control of nuclear safety. California emphasised that it was concerned with the economics of nuclear technology (to which the cost of waste disposal was a substantial addition) rather than its safety from radiation hazards. The State also noted that the decision of its Energy Commission relied on the findings of the federal government. Advocates of the nuclear industry and the United States agreed that Califormia was engaged in an ill-disguised attempt to regulate nuclear safety issues, the responsibility of the United States.

The Supreme Court, while recognising areas of federal nuclear supremacy, substantially favoured California's position. It thus gave state governments considerable ability to block nuclear development.
142 US Code $\$ 2011$ (a).

242 US Code $\$ 2021$ (a)(2)

342 US Code $\$ 2021$ (c)(1)

+42 US Code $\$ 2021(\mathrm{k})$.

-461 US $190(1983)$ 
${ }^{6} I d$ at 194.
7 Id at 205.
${ }^{8} I d$ at 212.
${ }^{9} I d$ at 223.
${ }^{10} 464$ US $238(1984)$.
${ }^{11} 110 \mathrm{~S} \mathrm{Ct} 2270(1990)$.
${ }^{12}$ Id at 2279.
${ }^{13}$ Long Island Lighting Co $v$ County of Suffolk, 628 F Supp 654 (ED NY 1986) (County attempt to interfere with federal emergency planning activity is unconstitutional); Stokes $v$ Bechtel North American Power Corp, 614 F Supp 732 (ND Cal 1985) (nuclear whistleblower's claims for improper discharge not pre-empted); Brafford $v$ Susquehanna Corp, $586 \mathrm{~F}$ Supp 14 (D Colo 1984) (punitive damages claim allowed in suit for radiation exposure); Brown v KerrMcGee Chemical Corp, 767 F.2d 1234 (7 Cir 1985) (state law injunction to remove waste materials intermingled with radioactive material is pre-empted); State of Nevada v Watkins, 914 F.2d 1545 (9 Cir 1990) (Nevada statute challenging federal actions to locate permanent nuclear waste repository is preempted); $O^{\prime}$ Connor $v$ Commonwealth Edison, 13 F.3d 1090 (7 Cir 1994) (federal radiation exposure standards must set standard of care in tort action); People ex rel Hartigan v Kerr-McGee, 568 NE.2d 921 (2nd Dist Ill 1991) (no pre-emption when state requires environmental permits that address nonradiological issues at thorium extraction facility).
The Court noted that the federal-state regulation of nuclear power had 'not been simple'. ${ }^{6}$ The 1954 Amendments to the Atomic Energy Act provided that the 'Federal Government should regulate the radiological safety aspects involved in the construction and operation of a nuclear plant, but that the states retain their traditional responsibility in the field of regulating electrical utilities for determining questions of need, reliability, cost, and other related state concerns'?

The Court noted that California could not 'regulate the construction of a nuclear powerplant'.$^{8}$ Even if non-radiation concerns motivated the state, this would intrude on the power of the United States. So too, California could not demand that its nuclear safety concerns be satisfied by the United States as a condition of licensing California nuclear plants. Nuclear safety standards were the prerogative of the United States and not subject to a state demand for higher standards.

California, however, had based its statute on economic, not safety reasons. Here, the United States Congress had not pre-empted state regulation either in section $2021(\mathrm{k})$ or in subsequent regulation. While promotion of nuclear power is a goal of the Atomic Energy Act, that goal was not to be accomplished 'at all costs'. As the majority opinion concluded: '.. the legal reality remains that Congress has left sufficient authority in the States to allow the development of nuclear power to be slowed or even stopped for economic reasons'?

Two subsequent Supreme Court cases reaffirmed the ability of state law to handle nuclear matters. Silkwood v Kerr-McGee Corp upheld a state tort law award of punitive damages for plutonium exposure of a worker in a federally licensed nuclear facility. ${ }^{10}$ English $v$ General Electric upheld a state law claim of intentional infliction of emotional distress for retaliation against a nuclear facility whistleblower." Here, the Court found too tenuous the connection between the harm to the worker (the goal of the state law) and the intrusion on federal control over nuclear safety. The Court insisted that the state laws need to have 'some direct and substantial effect on the decisions made by those who build or operate nuclear facilities concerning radiological safety levels'.12

Lower federal court cases have followed the guidance of the Supreme Court. ${ }^{13}$ State attempts to intrude on the federal prerogative in order to set nuclear safety standards have been struck down. However, states that avoid a safety confrontation have been able to assert their authority even where the state law proves to be a serious impediment to nuclear operations. In brief, direct confrontation with the federal government is likely to prove unproductive for anti-nuclear states and local governments. But, through indirect means the states have considerable power over nuclear operations. In addition, nuclear decision-making combines law, economics, politics, and public relations. These factors would be important in the State of Maine's involvement with Maine Yankee. 


\section{Hard times for Maine Yankee}

\section{Resleeving}

In July 1994, Maine Yankee discovered circumferential cracks in 303 tubes in the plant's steam generator system. ${ }^{14}$ Four of the July 1994 cracks had eaten more than 90 per cent of the way through the tube walls. ${ }^{15}$ The NRC had earlier cautioned plants about steam pipe cracks. ${ }^{16}$ The cracks threatened both tube efficiency and raised the prospect of radiation release if the tubes should break. ${ }^{17}$

The Summer 1994 discoveries did not raise great alarm. The NRC estimated that serious deterioration was not likely for another three years. ${ }^{18}$ By March 1995, however, optimism faded. Continuing inspections by the plant and the NRC found more cracks and cracks of greater severity. The NRC on-site inspector admitted to 'great concern'. ${ }^{19}$ The troubling question was whether the July 1994 inspections had not been adequate or whether the deterioration had accelerated at a far faster rate than expected. Neither was a cheering prospect and at the end of March 1995, Maine Yankee was shut down for an 'extended period' due to the tubing problem. ${ }^{20}$ Central Maine Power shares dropped 13 per cent in response to the bad news. ${ }^{21}$

In early April the Maine Yankee Board began assessing some difficult options. Full replacement of the steam generators appeared to be a $\$ 150$ million project. ${ }^{22}$ Repair, rather than replacement, was less expensive but still likely to cost $\$ 25$ million.

The extreme step was closure and the Board did address the prospect. ${ }^{23}$ Newspaper reports made certain that every Maine Yankee worker knew that they faced the prospect of redundancy in the immediate future. ${ }^{24}$

Near the end of May 1995, the Maine Yankee Directors voted a $\$ 40$ million repair project that involved inserting new metal sleeving inside the cracked tubes. ${ }^{25}$ Westinghouse was awarded the repair contract.

In October 1995, as the repair project progressed, the Governor of Maine appointed a safety review panel. ${ }^{26}$ The panel consisted of the two state nuclear officers and three academic engineers from Texas A \& $M$ and the University of Southern Maine. By early December, the team was ready to give the repair project high marks. Maine Yankee's euphoric publicists observed: 'If it was a report card, it would be all As' ${ }^{27}$ The repair project was on time and under budget and Maine Yankee appeared on its way to a renewed life. ${ }^{28}$

\section{Anonymous letter}

Trouble came from an unexpected direction in the form of an unsigned, undated letter whose author described himself as a former worker at Yankee Atomic Energy Company, the supplier of engineering services for Maine Yankee and other New England nuclear plants. The letter was sent to the Union of Concerned Scientists who on 1 December 1995, forwarded the letter to Uldis Vanags, Maine's

\footnotetext{
${ }^{14}$ Nucleonics Week, 16

February 1995, WL 7928370.

${ }^{15}$ Bangor Daily News, 11

March 1995, WL 5819581.

${ }^{16}$ Bangor Daily News, 10

January 1995, WL 5815351 .

${ }^{17}$ Id, 27 March 1995, WL

5822866.

${ }^{18}$ Nucleonics Week, 23

March 1995, WL 7928525.

${ }^{19}$ Bangor Daily News, 23

March 1995, WL 5822622.

${ }^{20} \mathrm{Id}, 28 \mathrm{March} 1995$, WL 5822929.

${ }^{21}$ Wall Street Journal, 28

March 1995, WL-WSJ

2122442.

${ }^{22}$ Bangor Daily News, 15 April 1995, WL 5824276.:

${ }^{23}$ Id, 8 April 1995, WL 5823801 .

${ }^{24}$ Id, 29 April 1995, WL

5825298.

${ }^{25}$ Id, 23 May 1995, WL

8760933.

${ }^{26} \mathrm{Id}, 25$ October $1995 \mathrm{WL}$

10897472.

${ }^{27}$ Portland Press Herald, 2

December 1995, WL

14383836

${ }^{28}$ Id, 15 December 1995 , WL 14482239
} 
Nuclear Safety Advisor. Vanags promptly sent the letter to the Nuclear Regulatory Commission. Within the week it was being reported in the press. ${ }^{29}$

The anonymous whistleblower did not criticise the tube resleeving operation. His concern was the 1989 request to uprate Maine Yankee from 2630 to $2700 \mathrm{Mw}_{\mathrm{th}}$. The letter stated that Maine Yankee and Yankee Atomic personnel had falsified safety information in order to secure the power upgrade. The primary focus was on deficiencies in the emergency core cooling system (ECCS) and in the computer code used to analyse a small break loss of coolant accident (SBLOCA). The accident at Three Mile Island had focused attention on the dangers of the core cooling system and the NRC had added new licensing standards to reflect lessons learned.

The letter detailed Maine Yankee's attempt to perfect a computer code that would indicate satisfactory margins of safety in the case of an accident. The codes showed just the opposite, that the ECCS was 'grossly inadequate'. Still Maine Yankee applied for the power uprate in part because the resident NRC inspector at Maine Yankee was about to be reassigned. The letter noted that the inspector 'was considered to be a particularly lenient person', therefore, Yankee Atomic wanted to get the approval before he left.Yankee Atomic also wanted to apply between Thanksgiving and Christmas when NRC staff were 'least vigilant'. The uprate was approved. When the NRC subsequently insisted on verification of the functioning of the ECCS, Maine Yankee offered 'fraudulent models' which 'did not even analyse a realistic accident and/or Yankee Atomic scenario'. In consequence, the whistleblower concluded: 'Maine Yankee . . . is operating on the basis of this fraudulent analysis at $2700 \mathrm{Mw}_{\text {th }}$ '. The author summarised with understated concern: 'I hope an occasion to use ECCS does not arise.'

A further section of the letter addressed deficiencies in the reactor containment system. Once again, it was reported that YAEC fraudulently excluded evidence that suggested an inadequate capacity to respond to a serious accident. What the letter called these 'tricks in the safety analysis' produced results that allowed the power upratings.

Despite the frequent use of 'fraudulent' and references to 'frequent violations of NRC regulations', 'ethical bankruptcy' and 'public safety concerns were put aside', the whistleblower was moderate in his suggested corrections. He asked that Maine Yankee be downrated to its original $2440 \mathrm{Mw}_{\text {th }}$ capacity, that it and YAEC be fined, and that one manager 'who used these activities for self-promotion . . . be seriously reprimanded'.

The letter was also notable for its attitude toward the Nuclear Regulatory Commission. The author observed the growing view within Yankee Atomic, where he worked 'that NRC is a nuisance of an organisation and its staff technically incompetent'. The author's decision to share his concern with a public interest group rather than 
The letter from the Union of Concerned Scientists endorsed the seriousness, if not the full credibility, of the charges. It recognised that the letter and accompanying documents indicated that a knowledgeable insider was responsible for the release. It urged disclosure to the NRC 'and the citizens of Maine'. The UCS also called for the State of Maine to demand 'a thorough, factual investigation' for public review. The letter of transmittal concurred with the whistleblower's scepticism about the NRC. 'I am convinced, based on 26 years of experience, that the NRC will not conduct such an investigation unless the State of Maine demands it.'

Response to the letter varied. The NRC promised an investigation, noting 'we are taking it seriously'. ${ }^{30}$ Maine Yankee's public relations director was dismissive: 'We don't feel there is any technical merit to these allegations'. ${ }^{31} \mathrm{NRC}$ investigators spent four days at Yankee Atomic interviewing staff and reviewing files. ${ }^{32}$ While the safety issues involved were different, the popular perception was that the letter and its investigation could delay the MaineYankee restart. ${ }^{33}$

The NRC investigation at Yankee Atomic discovered 'some legitimacy' in the letter. ${ }^{34}$ This was troubling news for Maine Yankee. Resumption of operation at $2700 \mathrm{Mw}_{\text {th }}$ now became unlikely.

As Christmas 1995 approached, the State of Maine appeared satisfied that the NRC was doing its job. ${ }^{35}$ As a Portland Press Herald editorial put it after praising Maine Yankee's 23 year safety record, the NRC course 'serves both reason and caution' ${ }^{36}$ The State's other leading paper, the Bangor Daily News was less charitable to both Maine Yankee and to NRC. 'The charges in the letter are clearly serious.' Maine Yankee 'has run on public trust . . . but now that fuel may be in short supply' ${ }^{37}$ Lastly, the NRC itself was under challenge from the whistleblower's allegation.

By early 1996, it was clear that two separate, but inter-related, questions faced Maine Yankee, Yankee Atomic, the NRC and the State of Maine. First, was the whistleblower correct that criminal fraud had taken place in the 1989 approval of the power uprate? While Maine Yankee and Yankee Atomic had abandoned the computer code in question, ${ }^{38}$ the prospect of prior criminal conduct posed an enormous problem. This was the stuff of melodrama conspiracy, conscious cooking the books in disregard of public safety. If the plant representatives were wilful, the NRC was only slightly better off. Their 1989 representatives appeared gullible. As the Governor asked about the on-site NRC inspector: 'What else did that guy miss?'

The second issue was whether Maine Yankee of 1996 was safe to operate at $2700 \mathrm{Mw}_{\text {th }}$, at $2440 \mathrm{Mw}_{\text {th }}$ or at all? That decision combined an assessment of the resleeving with an assessment of any other deficiencies that had surfaced or would surface in the wake of the whistleblower's letter.

At meetings in the second week of January, Governor King stated his position. At a meeting with MaineYankee President Charlie Frizzle, he received assurances that the plant was safe to operate.$^{39}$ Earlier, he had met with representatives of Maine's anti-nuclear groups.
${ }^{30} \mathrm{ld}$.

31 .

${ }^{32} / d, 15$ December 1995, WL 14482229.

${ }^{33}$ Id, 15 December 1995, WL 14482239.

${ }^{34}$ Id, 19 December 1995

35 Id, 21 December 1995, WL 14482688.

${ }^{36}$ Id, 22 December 1995 , WL 14482765.

${ }^{37}$ Bangor Daily New', 22 December 1995, WL

10901161 .

${ }^{38}$ Bangor Daily News, 6 February 1996, WL 2185472

${ }^{39}$ Portland Press Herald, 9 January 1996, WL 9558530. 
${ }^{40} I d, 10$ January $1996, \mathrm{WL}$ 9558607.

${ }^{41}$ Id.

42 Bangor Daily News, 11 January 1996, WL 2183807.

${ }^{43}$ Portland Press Herald, 12 January 1996, WL 9612770.

${ }^{44} I d, 16$ January 1996, WL 9613142.

45 Bangor Daily News, 6 February 1996, WL 2185472.

${ }^{46} I d, 24$ February 1996, WL 2186759.

${ }^{47}$ Time Magazine, March 1996.

${ }^{48}$ Portland Press Herald, 5 March 1996, WL 9619676.
The Governor also received direct assurances from NRC senior officials that Maine Yankee was conclusively safe to operate at the lower $2440 \mathrm{Mw}_{\mathrm{th}}$.

On 9 January, the Governor announced he would not oppose the restart of Maine Yankee. However, he characterised the anonymous letter as revealing a 'serious violation of the public trust'. He invited the author of this article 'to help him monitor the federal investigation into the letter's allegation' ${ }^{40}$

Nuclear opponents were distressed. William Linnell, their most quoted spokesman, said the Governor had 'sold out'. ${ }^{41}$ The Bangor Daily News accurately summarised the Governor's powers: 'The governor's legal authority to prevent the plant from starting on the NRC order is limited, but popular appeal allows him to influence the process. He should rethink his decision . . . and demand an independent investigation.' ${ }^{42}$ That view was countered by a Portland Press Herald editorial that could have been written by Maine Yankee's Public Relations Office: 'Every action taken by Maine Yankee's managers and state and federal officials has been appropriate . . All concerned Mainers can have confidence that Maine Yankee is safe at the projected level of operation.' ${ }^{43}$

By the end of January, Maine Yankee had returned to power production at $2440 \mathrm{Mw}_{\text {th }}$ Opponents continued to voice opposition to any operation of the plant and continued to emphasise the fraud in the 1989 uprating. ${ }^{44}$ They added their views that Maine Yankee's operation was unnecessary. Plenty of cheap replacement power was available to New England utilities.

By February 1996, Maine Yankee officials were showing optimism that the corner had been turned. Power production continued. The computer code involved in the 1989 uprating had been abandoned in favour of a newer model..$^{45}$ President Frizzle also repositioned the plant on the whistleblower's charges. In a speech in nearby Rockland he observed: 'It seems absurd to many people to have the federal government launch such a comprehensive investigation based upon an unsigned letter, but I wouldn't want it any other way'.46 'To a newcomer to Maine's nuclear controversies it would have seemed that Maine Yankee was pushing an excess of safety on the general public.

Again, the good news was short-lived. In early March, Time Magazine featured nuclear power as its cover story for the first time since the Three Mile Island accident in $1979 .{ }^{47}$ This news was no more favourable to the nuclear industry. The specific topic of the article was whistleblower allegations about the Connecticut Millstone nuclear plants. The general message was that the plants and the NRC were corruptly sustaining an unsafe industry.

Release of this article closely coincided with Maine Yankee's report that a leakage of gas at the plant had exposed 18 workers to small doses of radiation. ${ }^{48}$ The NRC filed charges against Maine Yankee for failure to follow procedures that should have prevented the exposure. Even the Portland Press Herald's editorial suggested 
that Maine Yankee was risking the 'public confidence' essential for its operation. ${ }^{49} \mathrm{~A}$ public meeting in Wiscasset revealed considerable distrust of the plant and the NRC. ${ }^{50}$

Serious bad news followed in early May with the release of a report by the NRC's Inspector General. ${ }^{51}$ The neutral watchdog of the Commission was sharply critical of aspects of the NRC's regulation of Maine Yankee. The NRC 'did not rigorously police' the plant. Its documentation was poor. Most pertinent to the anonymous letter were 'significant indications' that Maine Yankee 'hid problems in a safetyrelated computer programme'. The NRC was also characterised as too trusting of the plant operators. The NRC had been sharply criticised by its own Inspector General.

In these circumstances, a Maine-Yankee sponsored review of the whistleblower's allegations by a prominent regulatory law firm fell on deaf ears. ${ }^{52}$ The lengthy document concluded that Yankee Atomic and Maine Yankee 'might have mistakenly violated federal regulation, but have never misled regulators'. In essence, given the choice of an innocent or a culpable explanation the lawyers chose to find innocence. One year earlier the report's authors and its length might have purchased considerable credibility. In May 1996, it drew mostly scorn. The NRC responded that it would rely on its own investigation. ${ }^{53}$ State nuclear official Uldis Vanags suggested: 'This is just one side of the story'. ${ }^{54}$ Nuclear opponent Bill Linnell dismissed the report as only 'useful as lining for a litter box'.5s

\section{Independent Safety Assessment}

Following the IG Report, the Maine Governor called for a fully independent, non-NRC, review of the plant preferably by a national laboratory or other outside agency. The Governor continued to suggest nuclear power could be used profitably and safely, but Maine Yankee needed to get its act together. ${ }^{56}$

After much negotiation, a team to conduct an Independent Safety Assessment (ISA) was assembled in July 1996. ${ }^{57}$ The federal team was a combination of NRC officials and hired contractors. The 22 members were scientists, engineers and systems analysts with experience in the nuclear industry. They were joined by three members named by the Maine Governor King - the Nuclear Safety Advisor, the Nuclear Safety Inspector, and a consultant with expertise in analysing the operation of energy facilities. They were assigned to teams to study operations, maintenance and testing, engineering design and technology, management and organisations and the analytical codes. The codes investigation, however, would not review the codes involved in the whistleblower investigation, as those were the focus of the ongoing 'wrong doing' investigation.

The ISA team scheduled a rigorous three-month investigation. This would include two two-week periods during which the team was onsite in Wiscasset followed by collegial sessions in Washington. Maine Yankee promised its full cooperation. Both the Team leaders and
${ }^{49}$ Id, 4 April 1996, WL 9652614.

${ }^{50}$ Id, 30 April 1996, WL 9654615.

${ }^{51}$ Id, 12 May 1996, WL 9655576.

${ }^{52}$ Id, 30 May 1996, WL 10426220.

${ }^{53} \mathrm{Id}$.

${ }^{5} I d$.

$\leq I d$.

${ }^{56}$ Bangor Daily News, 1 June 1996, WL 2193118.

${ }^{57}$ Inside NRC, 10 June 1996 WL 8698327. 
Maine Yankee officials cautioned that such a massive investigation was bound to turn up problems.

Maine Yankee's pattern of embarrassing disclosures continued as the ISA moved forward. In early August the press reported the discovery that 'electric cables leading to the steam generators and reactor might not withstand a major accident' ${ }^{58}$ This could leave control room operators without necessary information on the status of the plant. A late August disclosure was even more disturbing. ${ }^{59}$ Workers discovered that a 15 -foot section of cable had been cut. While sabotage was possible, it seemed more likely the action had been taken for benign reasons but then forgotten. ${ }^{60}$

The ISA report was finally released in early October. The ISA statistics were impressive. The team had spent 4,500 man-hours at the plant. This was one-third more than the total cumulative annual NRC inspection time at Maine Yankee. The team conducted over 100 interviews and reviewed 100 shelf feet of documents. ${ }^{61}$ Assessments of different aspects of the plant were listed as 'superior', 'good' or 'adequate'. But the terms were NRC terms with particular NRC meanings. As a team leader commented, 'good isn't something to be proud of'. There was no category for 'unsatisfactory'; plants deemed unsatisfactory were plants not permitted to operate.

The ISA did not call for closure of the plant. There were positive reports in several areas. But the Report also identified serious shortcomings and troubling trends. The plant was 'generally in conformance with the licensing and design basis'. However, the old Maine Yankee plant lacked the specificity of newer plants. The design basis supported operation at $2440 \mathrm{Mw}_{\mathrm{th}}$. But operation at 2700 was ' $n o t$ demonstrated'.

Some of the significant problems surfaced in the review of operations. Most were discovered by team members and had evidently been overlooked or ignored by Maine Yankee prior to 1996. A telling statistic was that the infamous cut wire provided a six per cent increase in risk. Operations were also hampered by the cost-driven temptation to rely on 'work arounds', to continue operation without fixing the root problem. As one team member phrased it, the 'generate cheap' mentality was deeply ingrained.

Testing and engineering also came in for serious criticism. The lack of a questioning attitude hampered some operations. Other testing simply reflected 'dumb' approaches. Other areas suffered for lack of any person with supervisory responsibility.

${ }^{58}$ Bangor Daily News, 3 August 1996, WL 10704270.

s9 Id, 22 August 1996, WL 6874323.

${ }^{60}$ Portland Press Herald, 23 August 1996, WL 11239116 ; Wall Street Journal, 17 September 1996, WL-WSJ 11798670

${ }^{61}$ Portland Press Herald, 9 October 1996, WL 13305144. ${ }^{62} \mathrm{Id}$.
The full ISA Report was 100 closely spaced pages. The heart of it required significant technical background to understand, let alone interpret. For the press and the vast majority of the public, the introduction and the team leader's remarks in the public presentation would define the impact of the report. Here, the summary appeared to be an average plant safe to continue operation at $2440 \mathrm{Mw}_{\text {th }}$ with 'safety deficiencies' and a declining trend. ${ }^{62}$ The crucial root cause - why had the technical and operational problems arisen - was summed up in the finding of 'economic pressures to contain costs and poor prob- 
lem identification as a result of complacency and a lack of questioning attitude'.

\section{Legacy of the ISA}

The ISA Report marked a turning point for Maine Yankee. They promised to improve. The Board of Directors quickly endorsed a $\$ 10$ million expenditure programme. ${ }^{63}$ It also promised management changes to address the cultural problems. The NRC reminded everyone that the Report was only a first step. ${ }^{64}$ Maine Yankee was expected to report on its response in two months. The NRC Northwest Region Director explained that the Commission expected 'aggressiveness in identifying and solving' problems. ${ }^{65}$ It became clear that Maine Yankee faced the serious prospect of being placed on the NRC's 'watch list,' the strongest evidence of a troubled plant. ${ }^{66} \mathrm{~A}$ sharp drop in Central Maine Power's third quarter earnings highlighted the problem. ${ }^{67}$

The ISA report appeared at a troubled time for nuclear power in New England and nationally. Shortly before the Report's release the Boston Globe, the region's largest newspaper, ran a series on the safety and financial troubles of nuclear power in New England. ${ }^{68}$ The gloom continued with the speculation of mid-October that the Connecticut Yankee plant would close for financial reasons well before the end of its licensed life. ${ }^{69}$ And, in mid-October the NRC gave all nuclear plants 120 days to verify under oath that they were in 'compliance with the terms and conditions of your licence and NRC regulations. ${ }^{70}$ The Maine Yankee experience was helping to set national policy.

Dollars and promises were not enough to save Maine Yankee's management. Five days before Christmas, a unanimous Maine Yankee Board of Directors accepted President Frizzle's resignation. ${ }^{11}$

On 7 January 1997, the Louisiana-based Entergy Company was named as the new Maine Yankee operator. ${ }^{72}$ Entergy's track record of being willing to spend to correct problems struck a responsive chord with the Maine Yankee Board. While the Energy appointment resulted in some of Maine Yankee's best publicity, it was not without criticism. The contract between Entergy and Maine Yankee remained to be negotiated and was finally signed in February $1997 .{ }^{73}$ Both supporters and sceptics of nuclear power questioned what incentives Entergy would have to make a success of a plant that it did not own. Nuclear critics also noted that Entergy had earned a reputation for continuing operations while making repairs, a practice good for the economic bottom-line, but not necessarily for maximum safety. ${ }^{74}$

However high the praise for Entergy, it soon became clear that the new management would be tasked with the failings of the old. In late January, even before a new CEO arrived in Wiscasset, the NRC placed Maine Yankee on the 'watch list' ${ }^{75}$ The plant was placed on the Category II list which at least allowed it to return to service while correcting problems. Both opponents and neutral observers, however,
${ }^{63} \mathrm{Id}, 10$ October $1996, \mathrm{WL}$ 13305227.

${ }^{64}$ Portland Press Herald, 9 October 1996, WL 13305144

65 $I d$.

${ }^{66}$ Id, 17 November 1996 , WL 13308200 .

${ }^{67}$ Bangor Daily New's, 19

October 1996, WL 10708799.

${ }^{68}$ Boston Globe, 29

September 1996, WL 6879921

${ }^{69}$ Id, 10 October 1996, WL 6881043

${ }^{70}$ Portland Press Herald, 16 October 1996, WL 13305663.

${ }^{71}$ Id, 21 December 1996, WL 13310812.

${ }^{72}$ Portland Press Herald, 8 January 1996, WL 4114418.

${ }^{73}$ Portland Press Herald, 12 January 1997, WL 4114695.

${ }^{74} I d, 16$ January $1997, \mathrm{WL}$ 4115035.

${ }^{75} I d, 30$ January $1997, \mathrm{WL}$ 4116167 
sensed that permanent closure might be a realistic prospect.

In retrospect, events from April to August 1997 showed an inevitable movement to closure for Maine Yankee. When events were experienced day to day and week to week, however, good news alternated with bad. Certainly the news was not all bad. The overriding technical threat to Maine Yankee remained the condition of the steam generators. A thorough inspection began in March to assess the premature cracking that had ended the life of other nuclear plants. ${ }^{76}$ A potential $\$ 150$ million replacement was thought to be too great a burden for Maine Yankee management. By May, however, Maine Yankee reported that with 80 per cent of the inspection complete, the existing generators appeared in good shape. ${ }^{77}$

In May a new prospect emerged in the ever-newsworthy world of Maine Yankee - sale of the plant. After a few days of mystery, the Peco Corporation (the old Philadelphia Electric Company) identified itself as interested in the purchase of Maine Yankee from its present owners. ${ }^{78}$ Peco put forward its case. It was confident that it could make existing nuclear plants work safely and at attractive cost for the emerging deregulated electricity markets.

The price and other terms of sale were soon a topic of speculation. ${ }^{79}$ However, the bargaining positions suddenly took on a very different context with the unilateral announcement from Maine Yankee's Board on May 27 that the plant would be closed permanently unless a buyer was found. The Board also agreed to cut $\$ 41$ million worth of repair projects and lay off 900 contract employees. Maine Yankee CEO Mike Sellman observed: 'Every plant that has decided to curtail start-up activities has then gone on and shut down permanently.'

The following day, the Portland Press Herald summarised the factors motivating the Board. Repair costs, continued worries about the steam generator life, discouraging delays in negotiations with Peco, and doubts about Maine Yankee's competitiveness combined to sink the plant. Maine Yankee probably could not operate and generate power for less than five cents per kilowatt. That would not attract customers in a deregulated market.

All eyes turned to the Peco negotiations. On 7 June the Portland

${ }^{76}$ Portland Press Herald, 23 March 1997, WL 4120395.

${ }^{77}$ Bangor Daily News, 7 May 1997, WL 4762898.

${ }^{78}$ Portland Press Herald, 15 May 1997, WL 412452; Energy Daily, 16 May 1997 , WL 2025183.

${ }^{79}$ Nucleonics Week, 22 May 1997, WL 8870674

${ }^{80}$ Portland Press Herald, 7 June 1997, WL 4126369; Bangor Daily News, 9 June 1997, WL 4765212

${ }^{81}$ Bangor Daily News, 9 June 1997, WL 4765212.

${ }_{82}$ Portland Press Herald, 29 July 1997 , WL 12528061.
Press Herald disclosed 'confidential correspondence' that suggested the Maine Yankee-Peco talks were further along and more serious than Maine Yankee had first represented ${ }^{80}$ A letter from Peco to Maine Yankee spoke of using the next 30 days 'to determine if there are any conditions which would preclude our taking an ownership position' ${ }^{81}$

A 28 July Peco Board Meeting became the focal point for a 'gono go' decision. The reports from the meeting were favourable. Peco executives were given authority to keep negotiating about a purchase. A Peco spokesman observed: 'This is a big step forward,' but also noted 'significant financial issues still must be resolved' ${ }^{82}$

The cautious optimism of a Monday evaporated that Thursday with a call from the Peco CEO to Central Maine Power CEO David Flanagan. The message was blunt: 'No sale'. Maine Yankee remained 
willing 'to pay to have Peco take the plant' but the sticking point were repair costs and the decommissioning fund. Maine Yankee had only accumulated about $\$ 180$ million of an estimated $\$ 370$ million needed for decommissioning. And that estimate was widely felt to be too low. At the end of the day, the parties were "tens of millions of dollars' apart. ${ }^{83}$ Early in the following week a 35-minute conference call of the Maine Yankee Board admitted defeat with decisions to close the plant and send a formal notification of the fact to the NRC. ${ }^{84}$ One commentator, probably not intending a double meaning, headlined its story 'Maine Yankee Closes for Good' ${ }^{85}$

\section{Conclusion}

States and their citizens can remove nuclear power from their borders if they rely on non-safety reasons. In the case of Maine Yankee, the state and federal authorities cooperated in reviewing the plant's safety. The NRC ran the ISA. The state both participated and monitored the results. In 1996 both the NRC and the state found their interests advanced by discoveries of significant safety concerns and a general attitude of laxity on the part of the plant. The NRC needed to revalidate its reputation. A finding of only trivial shortcomings would not have been believed by the state, by the anti-nuclear community, or by the public at large.

The end result of the Federal-State collaboration involving Maine Yankee may be viewed that the operation was successful but the patient died. But the alternative of a Maine Yankee continuing to the end of its licensed life with major uncorrected safety defects is far more troubling. The message for other nuclear facilities is that state involvement in the federal process can be positive and effective. The nuclear plant that cannot meet the rigorous review of such a joint team should not operate. The ones that can may have a future in the new world of deregulated energy.
${ }^{83}$ Portland Press Herald, 3 August 1997, WL 12528431.

${ }^{84}$ Portland Press Herald, 7 August 1997, WL 12528748.

${ }^{85}$ Energy Report, 18 August 1997, WL 12976465. 